\title{
Tectonics \\ of the New World Order and the Russian Far East
}

Regional and Global Implications of Russia's Turn to the East

\section{Viktoria V. Panova}

\begin{abstract}
The author identifies key factors contributing to the development of the world's most dynamic Asia-Pacific region in the system of international relations, analyzes the role of players which are most important for the development of the region and the world in general, and outlines areas of their further interaction. Special attention is paid to the practical political and economic aspects of Russia's "pivot to the East." The first real steps to develop the Russian Far East and begin its full integration into the Asia-Pacific region were taken amid confrontation with Western partners, which somewhat limits the Russian state's possibilities for maneuver, but it would be completely wrong to say that this policy is "unnecessary" or abortive. Efforts to devise new rules of international relations and introduce new non-trivial instruments and practices are taking
\end{abstract}

Viktoria V. Panova, PhD in History, is Vice President for International Relations at the Far Eastern Federal University; Associate Professor at the Faculty of International Relations of the Far Eastern Federal University.

SPIN-RSCI: 9610-3245

ORCID: 0000-0002-1988-6476

Far Eastern Federal University

8 Sukhanov Str., Vladivostok, 690091, Russia

Tel: +7 (423) 2652232

E-mail: panova.vvl@dvfu.ru

victoria.panova@gmail.com

DOI: $10.31278 / 1810-6374-2018-16-3-90-109$ 
place amid the unfolding fourth industrial revolution which makes information a key commodity. If one fails to learn how to use the "case law" of the global ecosystem for finding solutions to both old problems within previous frameworks and constantly emerging new problems, he may end up on the sidelines of global development for good. Boldness and innovation should become the main driving force for the development of the Russian Far East and the Russian state as a whole.

Keywords: system of international relations, globalization, regionalization, Asia-Pacific region, China, India, the United States, development and integration of the Russian Far East.

\section{INTRODUCTION}

The global system of international relations is still trying to recover from the turmoil of the late 20th century: there is yet no new architecture of interstate relations, and the system keeps getting more complex, volatile and unpredictable. There are often not enough instruments for assessing properly prevailing trends or the political and economic thought, and there is also a lack of imagination on the part of researchers who offer non-standard views that go beyond such trends and concepts.

The dynamic nature of the current changes require both a fundamental analysis of almost simultaneous globalization processes and regionalization and fragmentation of the world order, and an empirical assessment of "building materials" and constantly changing "conditions of work" on the global construction site. The modern world is so multifaceted and multi-layered that it would be impossible to reduce the study of the region at issue to its purely geographic aspects. The purpose of this article is to assess the prospects of the "eastern vector" in Russia's foreign policy and economy in global and regional terms while refraining at the same time from delving too deep into comparative theorization (Solingen, 2015; Borzel, 2011.) on the nature of regionalism as such.

Some authors have lately observed a slowdown in the previously expected rapid development of "emerging nations," the most dynamic of which are located in Asia, particularly China, but it would be wrong 
to say that the Asia-Pacific region and its key players are losing their positions as the main driver in the development of the global economy (Jim O’Neil, 2018). Regional features require special methods and rules for building local cooperative systems (Acharya, 2016). It would not be possible to mechanically apply the European experience to these processes due to regional specifics. In this situation, while evoking growing interest and amity in Asia, it would be very important for Russia to choose a proper set of instruments for developing its Far East within the framework of regional and global development.

Although the current chaos and growing uncertainty in international relations create significant risks for each actor, seeming drawbacks can turn into additional opportunities and unexpected achievements. This gives Russia a chance.

\section{THE FRAMEWORK AND VARIABLES OF MODERN CHAOS}

The key process in the modern world is the continuing rebalancing of the center of world politics which is shifting from the "senior" developed countries, which for a long time were the core of development and exploited the periphery, and acted as the trend-setter for the entire international political and economic system. The European subsystem is actually falling out of the world political mainstream, and its role in global economic processes is declining. Today only three European countries-Germany, Great Britain, and France-rank among the world's top ten economies in terms of purchasing power parity. PricewaterhouseCoopers (2017) expects the situation to keep changing, with the share of the G7 countries in the global GDP shrinking to $20 \%$ by the middle of the current century (the U.S. is likely to fall behind not only China but also India in terms of purchasing power parity, and the share of EU countries will drop below 10\%). So, one can speak with certainty about the transition from the "centuries of Europe" to the "age of Asia" (Bordachev, 2018).

\section{WHY CHINA SHOULD NOT BE COUNTED OUT}

Although China's economic development has somewhat slowed down since the previous decade, it is still showing one of the highest growth 
rates in the world, achieving 6.9\% in 2017 (of all the G7 countries the highest growth rate of $3 \%$ has been reported only in Canada, which is half of China's indicator).

China, which for a long time preferred to keep a low profile and effectively used the "leading from behind" formula, gradually changed the region's configuration as its own possibilities increased. Unlike the United States' much touted "pivot to Asia," China consistently used multilateral initiatives and formats to consolidate its own positions in relations with its neighbors and partners in other regions. At the 18th Congress of its Communist Party in 2012, China set the task of developing diplomatic theory and innovative practices for promoting the so-called “Chinese dream." Two years later, in 2014, China publicly dropped Deng Xiaoping's concept in favor of foreign policy activism. Since then the country has made great headway not only in developing its own theory of international relations and global governance, but also in leading "the reform of the global governance system with the concepts of fairness and justice" (по Rudd, 2018). China's call for building a community of common destiny, made at the memorable 19 th party congress, is also quite interesting. Some researchers believe that there is a link between the improved economic position of China and its more active diplomatic efforts, which, in turn, strengthen the country's national identity (Ying, 2018).

For the sake of justice it should be said that China has not clearly opted for the role of global hegemon, and there is a certain lack of coordination in its intellectual and political establishment (see $\mathrm{Pu}$, 2017 for details). On the one hand, this is a tactical trick used by the Chinese leadership to test both external and internal reactions before taking real steps to realize the so-called "Chinese dream." On the other hand, such debates among Chinese and foreign researchers and practitioners expose a deep shift in their vision for the future of the world. Whether it is "triumphalistic" statements by Hu Angang, the director of Center for China Studies at the Tsinghua University, that China has already outdone the United States as the world's number one economic and technological power, or his opponents' strong reaction to these statements, who even urged the university to dismiss him 
(Huang, 2018); or it is "national revival" meaning efforts to regain the international status China once held during the Tang dynasty, gradually catch up with the current leader, the U.S., and achieve a bipolar equilibrium (Yan, 2014, 2016 (a,b)); or it is the absence of any plans to seize global leadership (Shambaugh, 2013) -all these views reflect both certainty about the most beneficial "positioning" for the future of China and speculation as to whether there will be a hierarchical world order with a new leader (or a return of the bipolar system) or a milder system without clearly defined centers or certain strong states' hegemonic aspirations (Kupchan, 2012). But in assessing the current situation we will be focusing not so much on the Chinese leaders' executive statements and debates among leading Chinese researchers about the future of the country as on practical foreign policy steps China has taken over the past several years.

China is the only BRICS country to have started using the national currency for payments with both other BRICS partners and a couple dozen other countries. While supporting the discussion on the modification of the existing international currency system, China is making its own moves in that direction as it gains stronger positions and no longer needs collective support. In 2016 this helped not only increase (albeit unevenly) the share of developing economies in the IMF quota and come close to having collective veto power, but also include the yuan in the IMF's SDR basket. This redistribution will continue in 2019 to favor economic development leaders.

China's growing confidence was clearly underscored by President Xi Jinping's initiative announced publicly in Astana, Kazakhstan, in September 2013. It revealed Beijing's global ambitions to create the Silk Road Economic Belt, which was later complemented with its maritime component (Maritime Silk Road of the 21st century), and the two made up the One Belt, One Road project, as well as with the supporting financial institutions-the Asian Infrastructure Investment Bank and the Silk Road Fund launched in October 2014. Despite the declared "Eurasian" context of the project, it largely transcends its boundaries to include other continents as well, thus leaving no doubt about China's leadership aspirations. Attempts to bring under control all the building 
blocks needed for both asserting China's status as a land power and advancing its ambitions to become a major maritime power essentially mean its claim to the next level of global development "from within," in contrast to the American geopolitical leadership "from the outside." Eventually, this may put the "aging hegemon" in the subordinated position, which is largely the real reason (not Trump's personality) for the current structural conflict between the two super powers.

\section{CHOOSING THE INDIAN ELEPHANT'S PATH}

Another quite predictable trend is the rapid economic rise of India, and the shift of the economic center of gravity to Asia. The future of India as one of the key global powers can be seen quite clearly. This is borne out not only by the size of its population comparable to China's (but much younger than that in China which will soon face the problem of aging) and similar GDP growth rates (6.7\% in 2017), but also by consistent foreign-policy moves undertaken in the past quarter of a century from acquiring a nuclear power status to becoming a member of authoritative international and regional organizations such as the SCO, BRICS, and the Group of Twenty. It should be said for the sake of objectivity, though, that India's GDP is about one-fifth of that of China.

But this is where all predictability ends. The future of the region becomes increasingly dependent on India's choice of broadening opportunities: which of the existing (or future) projects it will support and how its choice will correlate with current initiatives and affect its relations with other key players in the region and the world.

Yet joining the club of global players will hardly allow India to use the Non-Alignment Movement format tested before. There are two basic models for molding the regional landscape with India's participation. One is to accept the new American concept of Indo-Pacific Asia (initially proposed by Japan and Australia but later significantly modified to match the American vision and interests), which has replaced the equally artificial construct of the Asia-Pacific region, aimed to contain India's main opponent, China (Buzan and Waever, 2003; Lukin, 2011; Medcalf, 2018). Acting by the same logic, India is building closer military- 
political (Malabar naval exercises) and economic (Asia Pacific Growth Corridor) relations with Japan (Ghosh, 2017). The second option is to incorporate India's Act East Policy in the comprehensive Eurasian integration project, primarily from the point of view of China's global ambitions to form a "community of common destiny" and implement the One Belt, One Road project. When doing this, it will be necessary to take into account Russia's Eurasian Economic Union initiative as well as their mutually advantageous interconnection in the future.

India is balancing between these two constructs, trying to retain not only the room for political maneuver but also possibilities for tactical blackmailing of its geopolitical counterparts. India has a very close relationship with the United States, but it also is a member of the Quad that brings together the region's maritime democracies-Australia, India, the U.S., and Japan. Regardless of the domestic situation, India eagerly positions itself as "the world's biggest democracy" and distances itself from those countries which it and the liberal-democratic community do not qualify as such. This explains its continued focus on the India-Brazil-South Africa format (launched in 2003 but meeting quite irregularly) within the BRICS grouping and the reanimated idea of India's integration into the G7 as a slightly adapted version of the U.S. election slogan to create a League of Democracies proposed in 2008. However too much flirting with Western democracies to the detriment of continental Eurasian powers may deprive India of a number of political and economic preferences (suffice it to remember the constant U.S.-India confrontation in the WTO over the production of generic drugs, disputes over agricultural issues, or the adoption of the Countering America's Adversaries Through Sanctions Act (CAATSA), which jeopardized Russia's $\$ 400$ billion worth of military supplies, including S-400 missile defense systems, to India).

Choosing the Eurasian project is a milder way for India to join in the integration process (provided it has clearly defined its national interests) as it does not require it to give up close cooperation with outside countries. Cooperation among Russia, India, and China as well as within BRICS, and the admission of India and Pakistan into the SCO can be regarded as New Delhi's support for continental Eurasian projects. But on 
the other hand, with India aboard, the new "Eurasian Group of Eight" (there are eight members in the SCO now) is unlikely to support China's One Belt, One Road project just as enthusiastically as before.

Interestingly, some leading Indian experts believe that the current situation does not allow the country to rely on any of the existing centers of power (the West can no longer effectively protect the international order, but China's use of economic instruments for asserting its own norms and values is unacceptable for New Delhi). Moreover, such instability allows India to claim the status of great power, and for the first time since the end of World War II the country may offer a "New Delhi Consensus" and "is in a position to shape the international order" (Saran, 2018). And yet, while not denying India's independent role and possibilities to build a preferable regional configuration, it is quite hard to agree that New Delhi has sufficient material and nonmaterial resources to create new rules of interaction on the global scale without taking into account two key geo-economic competitors-the United States and China.

\section{A DIE-HARD EMPIRE}

Today the U.S. is a factor that rather increases global uncertainty than dispels it. While the previous decade was characterized by a standard set of geopolitical instruments designed to weaken the opponent and ensure U.S. dominance on the designated territory, now with Donald Trump in office, customary schemes are gone, at least for the time being. But Donald Trump's policy also fails to fit into the "offshore balancing" concept which allows the U.S. to retain its global leadership by setting potential regional aspirants against each other and counterbalancing them (Mearsheimer and Walt, 2016). In fact, America's Iran policy reveals a completely opposite logic and plays into the hands of its key competitor-China.

What exactly plays the pivotal role here-the American president's unpredictability and high-handedness, as many of his opponents claim (even though many experts note Trump's consistency in implementing his ideas announced earlier (Lukyanov, 2018)); the disruption of the established algorithm of political and diplomatic interaction and its 
replacement with business approaches and flashes of intuition, which allow the U.S. to get strategic advantages due to surprise effect; or a fundamental shift in American society towards neo-isolationism-has yet to be seen. So far we have seen Northeast Asia roll back to virtually the pre-war state of mobilization it was in in 2017, and an unexpected diplomatic denouement of the Korean crisis unfolding since January 2018, with Kim Jong-un and Donald Trump meeting in Singapore. U.S. relations with China were just as unpredictable: Trump's surprisingly positive remarks about President Xi after their meeting followed his previously unfriendly rhetoric about China. But then the two countries plunged into a trade war with each other. The Trump-Putin meeting in Helsinki seems to have added to uncertainty. In fact, for the time being there is still very minimal chance for a breakthrough in relations between the two countries.

On the one hand, experts are reproaching Trump for withdrawing from the world and concentrating too much on the domestic policy as the complete opposite of President Obama's "pivot to Asia." For example, the U.S. has so far failed to respond in a way similar to the post-war Marshall Plan to China's offer of economic bonuses as part of its One Belt, One Road project. The most outrageous move is Trump's withdrawal from the Trans-Pacific Partnership, his scandalous decision to revoke the U.S. signature under G7 documents, constant urging of his NATO partners to increase their defense spending, and his decision to stop subsidizing both trade partners and competitors. Interestingly, not only did the outbreak of the trade war with China anger the latter, but it also fueled reports about why the U.S. is doomed to lose this war (Stiglitz, 2018). For some reason, in this choir of condemnation by the American mainstream elite, the opposite views have largely been overlooked. For example, in his article Randall Schweller (2018) suggests taking a look at the results of Trump's policy both inside (record low level of unemployment, real estate market revival, a decrease in illegal migration) and outside (NATO allies have increased their defense spending compared to the year 2010) the country. On the other hand, the strategy of containing China was implemented consistently by the Obama administration through the "pivot to Asia" concept and a 
number of steps to foster bilateral and multilateral ties with APR countries in a bid to restrict China's freedom of action. But it is this allembracing approach that resulted in a series of Washington's defeats suffered from Beijing. Despite the U.S.s strong criticism of the Asian Infrastructure Investment Bank initiative and calls for boycotting it, its closest allies, including Great Britain, jumped on the bandwagon. Another blow came when China started to build seven artificial islands in the disputed parts of the South China Sea in 2017. Add the deteriorated relations between the U.S. and the Philippines and President Duterte's rude remarks about Obama. So the failure of the pivot to Asia can hardly be blamed solely on Trump. Its incompleteness could not be made up for even by Obama’s Trans-Pacific Partnership plan, which was later scrapped by his Republican successor. Besides, it is the Trump administration that has breathed new life into the Indo-Pacific region concept as a mega-regional security complex which may somewhat reduce China's global possibilities by engaging and supporting India.

Given the previous administration's setbacks in the region, Trump's current steps can be compared with the tactics North Vietnamese guerrillas employed against regular American troops. Traditional instruments did not work or were not sufficient, the moment when the opponent was weak was missed, and now the U.S. has to save the situation to avoid full loss of positions in Asia. This generates "national egoism" and the "America first" principle (in plain terms, this means the priority of American interests, or as Trump put it, "principled realism") which the U.S. president believes should lie at the core of any country's foreign policy.

\section{BEST SUPPORTING ACTOR NOMINATION}

Many are complaining that this policy is pushing U.S. allies away. But the emergence of a network of strong and independent Pacific states in the changing global system serves U.S. interests in the best possible way. For example, after Trump had urged his allies to do more for their own security, Japan's right-wing nationalists, and incumbent Premier Shinzo Abe may be considered their representative, have for the first time since the end of World War II got a chance to realize their dream of restor- 
ing Japan's great power status. In the current situation, seeing Japan as a more independent and combat-capable ally would be much more preferable for Washington than having it as a client with limited sovereignty.

A similar situation is evolving around South Korea, one of the most loyal and devoted U.S. allies. After the election of Moon Jae-in the Republic of Korea has been showing more independence in pursuing its vital interests, including inter-Korean settlement. Relative freedom given to the South Korean president and the North Korean leader's bold moves became important factors that allowed them to hold their first meeting and plan another one, and paved the way for the TrumpKim talks in Singapore.

\section{DEVELOPMENT FRONTIERS}

But what is the role of Russia and its Far East (Pacific Russia) in the intricate entwinement of interests and in building a new regional and global political system?

The Europe-Asia dialogue mechanism ACEM, which Russia joined in 2010, is an interesting example. Both partners for a long time refused to admit Russia, saying it was neither Europe nor Asia but something else. Today, Russia is officially included in the group of Asian members of the forum. While Russia sometimes thinks of itself as a bridge connecting Asia and Europe, experts say that Asian countries have at last started viewing it as one of their own (Karaganov, 2018).

The Far East for Russia is not only a source of valuable natural resources and gateway to Asian and Pacific markets, but also a strategic line of defense giving the country free access to the Pacific Ocean and sovereign control over the eastern section of the Northern Sea Route. The region also has "the potential of cold" as an additional climatic and geographic advantage for the development of digital economy and a real storage space for large amounts of data.

This makes the place of Russia and its Far East in the Asia-Pacific region quite unique. Access to the seas in the Pacific and Arctic Oceans makes Russia both a continental and maritime power, with all the inherent advantages and problems. The Russian Far East is not the periphery but on the contrary a place where three "tectonic 
platforms"-Eurasia, the Pacific, and the Arctic-meet. In May 2018, the presidential envoy to the Far East, Deputy Prime Minister Yuri Trutnev received more powers to oversee Arctic development. This is a clear indication that the Kremlin is well aware of the current fundamental geopolitical trends.

Despite the active rise, at least in a discursive form, of Eurasian continentalism, the importance of the Asia-Pacific region is not declining. On the contrary, it is increasing. One of the indicators of that is the growing strategic competition between the U.S. and China underlain by the struggle for leadership in the Asia-Pacific region. At the end of the 20th and the beginning of the 21 st centuries, the U.S. exerted a lot of effort to fill the vacuum of power in Central Asia. The main foreignpolicy and military documents adopted by the Trump administration-National Security Strategy and the National Defense Strategyname China as America's main opponent, with Russia coming second.

In contrast to American straightforwardness, Beijing's natural eyemindedness does not allow it to openly name its geopolitical opponents even though Beijing's military-strategic preparations leave little doubt that its focus is on the Pacific theater and its purpose is to avoid a situation where a hostile country could land-lock China. Its previous President $\mathrm{Hu}$ Jintao started to shift the focus in the national military doctrine from land warfare to a stronger navy and tighter control of seas in the region. To this end China moved to create a 300-mile territorial water zone and exercise effective control over it, strengthen the country's maritime sovereignty in the disputed territories, ensure blue-water defense capability, carry out reunification of the country, commission new aircraft carriers, build nuclear-powered submarines and so on (Ponomarev, 2007). President Xi Jinping placed even more emphasis on the task of making China a great maritime power. Work is already underway. The scale of naval development in China is truly amazing. In fact, Chinese aircraft carriers, destroyers and submarines are hardly intended for Eurasian steppes and mountains. Their mission is to turn the country into a great Pacific power.

As China builds up its military strength and increases control over the seas in the region, we may soon see its own "Monroe Doctrine" 
in the Asia-Pacific region (Mearsheimer, 2018), and its identification friend or foe air defense system in November 2013 became the first step in pushing "alien countries" out of the region. The geopolitical and geo-economic center of gravity in the Asia-Pacific region, even in its fashionable Indo-Pacific form, lies in Northeast Asia, of which Russia's Far East is part. Northeast Asia is a knot of multidirectional trends. On the one hand, there are lingering contradictions between Asian majors-China, Japan, and South Korea-deftly stoked up by the United States. Americans are worried, not without reason, about a possible emergence of an "Asian bloc" that will challenge the dominance of the Euro-Atlantic integration zone. But Northeast Asia is steadily moving towards a single integration zone, institutionalized by the CJK grouping (trilateral cooperation between China, Japan, and South Korea). In May 2018, they held their new summit. In the foreseeable future, North Korea, which is now getting out of isolation, may join the grouping. Russia's task is to find the most advantageous way to get engaged in these integration processes too. This is the only architecture which can allow Russia to resolve one of its main dilemmas. According to a leading Russian international relations expert, Alexander Lukin (2018), Moscow is facing "a growing collision between its desire to see Northeast Asia as a region free of hegemony and the deepening 'quasi-union' with its main 'strategic partner"'. In this context, along with Beijing, Tokyo, Seoul, and probably Pyongyang, Vladivostok can and should become one of the capitals of the Northeast Asian community.

\section{WHO CAN BENEFIT FROM PLAYING REQUIEM FOR RUSSIA'S FAR EAST?}

The transformation of the Far East (especially if considered as a meeting point of three major geopolitical players-continental Eurasia, the Pacific, and the Arctic) into Russia's development frontier will hardly please some people. These include not only foreign competitors who fear the emergence of a new center of power in a strategic region, but also some Russian citizens who feel quite comfortable in the quagmire of periphery, neither interesting nor attractive, which is doomed to eke out its existence among truly important regions (be it Northeast 
Asia, the North Atlantic or the center of Eurasia). In fact this is the only logic that can lead one to regard the Far East as an unsovereign object of international relations which may or may not be of interest to other sovereign subjects.

One cannot but agree that Moscow waited too long before setting its eyes on the Asian part of the global economic and political space. It should have noticed Japan's transformation into the second largest economy during the Cold War and Deng Xiaoping's process launched in China at the end of the 1970s.

The end of the Cold War, the collapse of the socialist bloc and the disintegration of the Soviet Union forced Moscow to focus on the survival of the new Russian state. Today, the means of survival chosen by the ruling elite at that time seem somewhat unsuitable, to put it mildly, as they largely laid the groundwork for the current crisis in relations between Russia and the West.

It took time to absorb the multi-vector foreign policy course proposed by Yevgeny Primakov. The theory of foreign policy diversification and the first attempt to form the Russia-India-China triangle of cooperation did not lead to a complete revision of Russia's political and economic priorities. Although the first documents adopted at the end of the 1990s theoretically substantiated the need for a partial reorientation to the East and comprehensive economic development of territories beyond the Urals in cooperation with APR countries, the adoption of practical decisions was delayed for more than a decade.

The strategic mentality of most members of Russia's political elite remains inertial, and this factor should not be underestimated. The effective Russian Foreign Policy Concept mentions Asia-Pacific countries only after all post-Soviet and Euro-Atlantic counterparts (Concept, 2016). This is a serious negative signal to Asian partners, which is reflected in the documents prepared by China for its business people in order to determine whether Russia would be attractive for their investments (based on the research, not yet published, undertaken by two Far Eastern Federal University graduate students: "Economic Attractiveness of the Russian Far East as Part of the Asia-Pacific: Case of China," 2018). 


\section{"FIRST SPEED" FOR THE FAR EASTERN TRAIN}

And yet there is more to the development of the Far East and its integration into the Asia-Pacific region than just the Kremlin's rhetoric. In 2000 the country was divided into federal districts and the Far East got its first presidential envoy and in May 2012 a special ministry for the development of the region. It became finally clear that equal and mutually advantageous cooperation with APR countries could be possible only if the Russian Far East were competitive and strong.

With the first decade of the new century gone, Russia is only beginning to take concrete steps. So it would be premature to speak about the results of the "pivot to the East."

In 2012, Vladivostok hosted an APEC summit, followed by such initiatives as the Fast Eastern hectare (relevant federal law was adopted only in July 2016), territories of advanced development (federal law adopted in December 2014), the free port of Vladivostok, and others. All these initiatives are slowly beginning to bear fruit, and the region becomes more attractive to investors and tourists. Under the agreement signed by the governments of Russia and China in 2000, tourist groups from the two countries can travel to each other's territory without visas. Electronic visas are another novelty. Although it was introduced in August 2017, about 13,000 foreign guests (98\% from China and Japan) have already visited the region using the fast-track border procedure, even though the overall number of tourists in the first half of 2018 exceeded 316,500 people. But the region can easily accommodate more.

Along with "institutional problems" in the region (imperfect legislation, non-compliance with effective laws, lack of transparency in relations between business and the authorities, underdeveloped infrastructure in the Far East), one of the critical issues for the region's development is a low population density. This limits potential foreign investors' economic gains. About $80 \%$ of current investments in the Far East are Russian. Several cross-border regional cooperation projects launched by Russia and China have also failed (Zuyev, 2018). However there are several big joint projects too: Russia and South Korea are planning to build a mineral fertilizer plant in the Nakhodka District; the Canadian company Kinross Gold is working in Chukotka; Singa- 
porean investors have bought a stake in Knevichi Airport to become its co-owners; and there are some other large investment programs as well. All this is happening despite sanctions and the reluctance of major Asian businesses to take high risks.

On the other hand, there are factors that allow Russia to capitalize on the positive dynamics of bilateral relations and projects proposed by the leaders of neighboring countries. These include South Korean President Moon Jae-in's nine bridges initiative which is acquiring an additional dimension in light of the latest political warming on the Korean Peninsula (by resuming South Korea's participation in the Hasan-Rajin railway project, building a trans-Korean railroad and connecting it with the Trans-Siberian Railway, carrying out joint energy projects, etc.). Japanese Prime Minister Shinzo Abe earlier proposed an eight-point plan for the development of economic relations. Three years ago Presidents Vladimir Putin and Xi Jinping agreed to integrate the Eurasian Economic Union and the One Belt, One Road projects. It is also important to support Asian investors who are already working in the Russian Far East. In fact, their success stories will help bring new investments into the region.

There is yet one more factor to remember. Modern digital economy gives priority not so much to material resources as to human capital. The creation of federal districts in Russia was followed by the establishment of federal universities in each of them to raise young talents in their respective regions. The Far East is one of them. The Far Eastern Federal University is carrying out the mission of integrating Russia into Asia Pacific and driving the development of the region not only by training qualified personnel but also by launching international scientific, educational, and innovation projects. In September 2017, the Russky Technology Park was inaugurated at the University within the framework of the Eastern Economic Forum to boost the high-tech development of the Russian Far East.

No matter how turbulent the transformation of the system of international relations and changes in the position of regions and the role of 
actors on the global chessboard may be, and no matter how incongruous new geopolitical constructs look, the significant development potential of Pacific Russia remains a constant variable. The key question is whether Russia is prepared to take risks and offer innovative solutions to tap this potential in the right way to facilitate the development of the whole country and its integration into the changing international networks on mutually advantageous terms. Russia should learn to use "case law" of the global ecosystem in order to solve existing and emerging problems, while drawing on the rich historical experience of interaction with European and Asian countries, studying, but not copying, the best foreign practices, and taking inventory of the initiatives in progress and new instruments. Otherwise, it will risk ending up on the sideline of history for good.

Withdrawal from previous paradigms and established political constructs also provides additional possibilities for Russia's foreign policy aspirations. The Far East as a meeting point of three key regions-Eurasia, Pacific Asia, and the Arctic-opens up prospects for overcoming a false dilemma of traditional division into continental (and integration with continental Eurasia) and maritime (deeper engagement with the Asia-Pacific region) states. Russia's dual geopolitical nature allows it to move along both tracks at the same time, complementing rather than excluding each other.

But the success of this strategy will depend not only on the traditional components of state power. This is why a crucial factor of the Russian Far East's successful integration into the space of advanced innovations is a sufficient population, well educated, creative and committed to building its own future.

On the one hand, the outflow of people from the Far East continues, and the remaining six million cannot make a breakthrough in development, especially next to dynamically growing Pacific states. On the other hand, the federal government's attention (albeit still not sufficient yet) is slowly beginning to transform people's mentality in the Far East from feeling abandoned and offended to being the ones who can make the difference and determine the future of not only their region but of the whole country. Clearly, it is harder for the senior 
generation to adapt, but it is young people who are building the future and it is up to them to advance the Far East to leading positions in the country and the Asia-Pacific region. Young people will have to decide whether the Far East is the periphery or a new frontier and one of key centers of the new global geopolitics.

\section{References}

Acharya, Amitav, 2016. Security pluralism in the Asia-Pacific: reshaping regional order. Global Asia, 25 March. [online] Available at: <https://www.globalasia.org/v11no1/cover/security-pluralism-in-the-asia-pacific-reshapingregional-order_amitav-acharya>

Acharya, Amitav, 2009. Whose ideas matter? Agency and power in Asian regionalism. Cornell University Press.

Bordachev, T., 2018. "Dve voinny" Zapada i Rossiya: priroda mezhdunarodnogo krizisa I chto eto znachit. ["Two wars" of the West and Russia: the nature of the international crisis and what it means]. Russia in Global Affairs, 11 July. [online] Available at: <http://www.globalaffairs.ru/number/Dve-voiny-Zapada-iRossiya-19666 [Accessed 25 July 2018].

Borzel, T., 2011. Comparative regionalism: a new research agenda. KFG Working Paper, No. 28, August. Free University of Berlin.

Buzan, B. and Waever O., 2003. Regions and powers: the structure of international security. Cambridge: Cambridge University Press.

Ghosh, Madhuchanda, 2017. India's strategic convergence with Japan in the changing Asia-Pacific geopolitical landscape. East West center. Asia Pacific Bulletin, \#392, 16 August. [online] Available at: $<$ https://scholarspace.manoa.hawaii. edu/bitstream/10125/48495/1/apb\%20no.392.pdf> [Accessed 19 July 2018].

Huang, Cary, 2018. China's social media users call for sacking of 'triumphalist' academic, as anti-hype movement grows. South China Morning Post, 3 August. [online] Available at: <https://www.scmp.com/news/china/policies-politics/ article/2158054/chinas-social-media-users-call-sacking-triumphalist $>$ [Accessed 15 August 2018].

Karaganov, S., 2018. V 2017 godu nas v Azii stali schitat svoimi [Asia takes us as one of its own in 2017]. Rossiya v globalnoi politike [Russia in Global Affairs], 5 February. [online] Available at: $<$ http://globalaffairs.ru/pubcol/V-2017-godunas-v-Azii-stali-scitat-svoimi-19336> [Accessed 19 July 2018]. 
Kupchan, Ch., 2012. No one's world: the West, the rising rest, and the coming global turn. Oxford University Press.

Lukyanov, F., 2018. Takoī predskazuiemyī Trump: o strategii i taktike prezidentstva SShA. [Such predictable Trump: on the strategy and tactics of the U.S. presidency]. Rossiya v globalnoi politike [Russia in Global Affairs], 25 June. [online] Available at: <http://www.globalaffairs.ru/redcol/Takoi-predskazuemyiTramp-19630> [Accessed 20 July 2018].

Lukin, A., 2011. Teoriia kompleksov regionalnoī bezopasnosti v Vostochnoī Azii. [The theory of regional security complexes in East Asia]. Oikumena, \#2, pp. 7-19.

Lukin, A., 2018. Russia and the United States in the Asia Pacific: a perspective of the English school. Asian Perspective, 42, pp. 307-331.

Mearsheimer, J., 2018. RIP Taiwan? The National Interest, 24 July. [online] Available at: <https://nationalinterest.org/blog/skeptics/rip-taiwan26676? page $=0 \% 2$ C6 $>$ [Accessed 30 July 2018].

Mearsheimer, J. and Walt, St., 2016. The case for offshore balancing: a superior U.S. grand strategy. Foreign Affairs, July/August, pp. 70-83.

Medcalf, R., 2018. Reimagining Asia: from Asia-Pacific to Indo-Pacific. In: Rozman, G. and Liow, J.C., eds. International relations and Asia's southern tier: ASEAN, Australia and India. Asan-Palgrave Macmillan Series.

O’Neill, J., 2018. New rules for the new global economy. Project Syndicate, 27 July. [online] Available at: <https://www.project-syndicate.org/onpoint/new-rules-forthe-new-global-economy-by-jim-o-neill-2018-07?utm_source=Project+Syndica te+Newsletter\&utm_campaign=c2d055707d-op_newsletter_2018_27_07\&utm_ medium $=$ email\&utm_term $=0 \_73$ bad5b7d8 $-\mathrm{c} 2 \mathrm{~d} 055707 \mathrm{~d}-93556209 \& \mathrm{mc}$ _ cid $=c 2 d 055707 d \& m c \_e i d=2 a 00 a d 3533>$ [Accessed 30 July 2018].

Ponamarev, S., 2007. KNR: novaia velikaia morskaia derzhava? [China: a new great maritime power?]. Index bezopasnosti, \#2 (82), Vol. 13. [online] Available at: <http://www.pircenter.org/media/content/files/0/13413054730.pdf> [Accessed 20 July 2018].

$\mathrm{Pu}, \mathrm{Xiaoyu}, 2017$. Controversial identity of rising China. The Chinese Journal of International Politics, Vol. 10, No. 2, pp. 131-149.

PwC: k 2050 godu Rossiia stanet pervoī ekonomikoī Evropy. [PwC: Russia to become Europe's number one economy by 2050]. RIA Novosti, 7 February. [online] Available at: <https://ria.ru/economy/20170207/1487362240.html> [Accessed 20 July 2018]. 
Rudd, K., 2018. Xi Jinping's vision for global governance. Asia Times, 15 July. [online] Available at: <https://www.atimes.com/xi-jinpings-vision-for-globalgovernance/> [Accessed 20 July 2018].

Saran, Samir, 2018. As India turns 71, what is the rising global power's vision for the world? Observer Research Foundation commentaries, August. [online] Available at: $<$ https://www.orfonline.org/research/43348-india-turns-71-whatrising-global-power-vision-world/> [Accessed 30 August 2018].

Schweller, R., 2018. Three cheers for Trump's foreign policy: what the establishment misses. Foreign Affairs, Sep/ Oct. [online] Available at: <https://www. foreignaffairs.com/articles/world/2018-08-13/three-cheers-trumps-foreignpolicy> [Accessed 3 September 2018].

Shambaugh, D., 2013. China goes global. Oxford University Press.

Solingen, Etel, 2015. Comparative regionalism: economics and security. Routledge.

Stiglitz, J., 2018. The U.S. is at risk of losing a trade war with China. Project Sydicate, July. [online] Available at: <https://www.project-syndicate.org/commentary/trump-loses-trade-war-with-china-by-joseph-e--stiglitz-2018-07>

Yan, Xuetong, 2014. From keeping a low profile to striving for achievement. The Chinese Journal of International Politics, Vol. 7, No. 2, pp. 153-184.

Yan, Xuetong, 2016a. Political leadership and power redistribution. The Chinese Journal of International Politics, Vol. 9, No. 1, pp. 1-26.

Yan, Xuetong, 2016b. Urging China to adopt a more assertive foreign policy. New York Times, February. [online] Available at: <https://www.nytimes. com/2016/02/10/world/asia/china-foreign-policy-yan-xuetong.html?_r=3> [Accessed 25 August 2018].

Ying, Liu, 2018. Strategic partnership or alliance? Sino-Russian relations from a constructivist perspective. Asian Perspective, 42, pp. 333-354.

Zuenko, I., 2018. Pochemu Rossiia i Kitaī provalili programmu prigranichnogo sotrudnichestva [Why Russia and China failed with the cross-border cooperation program]. Carnegie Moscow Center, 22 August. [online] Available at: $<$ http://carnegie.ru/commentary/77081> [Accessed 25 August 2018].

Kontseptsia..., 2016. Kontseptsia vneshneī politiki Rossiiskoy Federatsii [Foreign Policy Concept of the Russian Federation]. [online] Available at: <http:// www.mid.ru/foreign_policy/news/-/asset_publisher/cKNonkJE02Bw/content/ id/2542248> [Accessed 24 July 2018]. 